\title{
Liquidity Problems in Islamic Banks; Reasons, Impacts and Solutions
}

\author{
Amir Islam ${ }^{1}$, Sabeen Amir \\ ${ }^{1} V P M C B$ Islamic
}

\begin{abstract}
The purpose of the research is to study the types of liquidity problems in Islamic banks, to analyse the causes of liquidity problems along with their impacts on Islamic banking industry with the objective of finding solutions to the liquidity problems of Islamic banking industry (IBI). The study design was based on primary research conducted through development of a questionnaire along with the interviews of Shariah advisors. The questionnaire was distributed among the Islamic bankers engaged in liquidity management process working at senior and middle management level. The study initially examined liquidity problems in Islamic banks along with the mitigation techniques employed by the Islamic banking industry to control them. Thereafter, the study highlighted shortfalls in bank practices or non availability of Shariah compliant mitigation tools. Finally, the study discussed Shariah compliant mitigation techniques to tackle different kinds of liquidity problems in Islamic banks and suggested solutions to the problems.
\end{abstract}

The study revealed that liquidity problem in IBI consists of two opposite facets i.e. surplus liquidity and liquidity crunch and most of the Islamic banks faced both kinds of liquidity problem at different times. The study further elaborated key factors affecting liquidity position of Islamic banking industry. The study also found that the role of Shariah advisors is all the more important in IBI. The results of the research divulge that Islamic banks can solve liquidity problem through issuance of sukuk bonds against their long term portfolio as well as through the development of common Musharika pool to be regulated by Central bank. The paper may be of value to the global IBI, central banks as well as conventional banking industry, academic institutions along with researchers for additional research.

Keywords: Liquidity Management, Islamic Banks, Financial Institutions, Shariah, Mitigation Techniques, Islamic Financial Institutions.

\section{Introduction}

The last ten years have witnessed absolutely tremendous growth of the Islamic banking industry. This awesome progress of Islamic banking is not only limited to the Islamic world but also took by surprise the West and other non-Muslim countries across the globe. The current status of Islamic banking is an evidence of a firm financial platform which was just no match for the conventional banking industry, merely a few years into the past. Making reasoned comparisons reveals the resilience shown by the Islamic banking industry during the course of the recent global financial crises which has dealt a heavy blow upon the foundations of even well-established financial institutions in all parts of the world. On the other hand, the global Islamic financial market gained sharp momentum after the crises. At the moment, global Islamic banking assets are estimated around US\$ 1.7 trillion and are projected to grow to US\$ 3.4 trillion by 2018 (Ernst \& Young, 2013). Seemingly, countries like Qatar, Indonesia, Saudi Arabia, Malaysia, U.A.E., Turkey and Pakistan will be the most consequential contributors as there are a lot of untapped opportunities waiting to be explored by the Islamic Banking industry.

Besides the potent behaviour of Islamic Banking industry, major grey areas negatively impacting the profitability of Islamic banking is the efficient allocation of funds side by side with the stimulation of funds against their commitments, also known as liquidity management in financial terms. The arena of liquidity management is a sum of two opposing spheres:

1. Liquidity Risk or management of shortfall in funds

2. Management of surplus liquidity.

Corresponding Author: Amir Islam, email: amir_islam@hotmail.com

(c) COMSATS Institute of Information Technology Lahore, Pakistan.

Vol. 1, 2016, pp. 1-9 
Banks usually generate two types of deposits, remunerative and non-remunerative. In respect of liquidity management, funds are classified on the basis of their tenors and maturities, and henceforth the asset positions are assumed in order to attain and maintain equivalence between the assets and liabilities, keeping a part of funds in hands to meet the deposit commitments. This art of maintaining a balance between assets and liabilities is known as Balance Sheet or Asset- Liability management. Mismatch between deposits and investments propels liquidity risk, no matter whether it is a conventional bank or an Islamic Bank. Additionally, the risk of holding too much liquidity is ever present, which, then goes forth to upset the profit motive of an organization. Maintaining the accurate balance between the motives of profitability and safety is the crux of Liquidity Management (Chapra and Habib, 2002). Such management in IBI demands a different approach, carrying an additional all time Shariah compliance attribute due to these reasons:

- Islamic banking industry is restricted to convert funds into real assets which is a time consuming process. Unutilized funds of an IB give rise to both expense and liability and, simultaneously adversely impact the profit rate of the saving deposit pool, which may consequently decrease the deposit base of the bank.

- On the other hand, if an IB is facing liquidity crunch, it is forced to enhance the profit rates to attract more deposit and may not be able to raise the call options for early adjustment of financing due to commitments against Shariah based agreements, as is the case in conventional banks.

- The probability of maturity mismatches in the assets and liabilities of an IB as compared to a conventional bank increases many times owing to the fact that the asset side of an Islamic bank is like a fixed investment where repayment period and repayment amount is fixed, without any option available to an Islamic bank to raise call option in case of need. On the other hand, the liability side or deposit side of the bank is dependent entirely on depositor's behaviour and depositors enjoy an all-time option to withdraw deposit as and when they choose. Thus, the balance sheet structure of an IB poses a liquidity threat.

- Due to Shariah compliant agreements, on the asset side, Islamic banks are prohibited from deriving additional profit on delayed payment, rather delayed payment seriously impairs profitability of an IB which is not the case in conventional banks as conventional bank charge penal rate of mark up in case of delay. Moreover, no benefit can be passed to the customers in case of early payments against the financing exposure.

- For an IB, the option of funds generation and placement through treasury bills, bill discounting, overnight borrowing, overnight repo, open repo and term repo etc. is totally proscribed as these are interest based loan transactions, whereas such options are habitually exercised by the conventional banks.

- The regulatory requirements like SLR \& CRR are more stringent in case of an IB because of no return on placement of funds with State Bank of Pakistan in the absence of Islamic channels for placement of SLR. In contrast, the conventional banking industry reaps rich return from interest based SLR eligible securities.

- Most assets of Islamic banks are predominantly debt-based, these become illiquid due to Shariah restrictions on sale of debt at a higher or lower price, which is not the case in conventional banks.

The above discussed dissimilarities with conventional banks highlight serious constraints on part of Islamic banks, and hence demand a combination of prudence and efficiency as far as liquidity management goes. The study showed that conventional banks enjoyed better profitability and liquidity risk management than Islamic banks because of their superior performance in the field of assets and return (Akhtar et al, 2011). This makes clear that in the backdrop of the present impressive performance the IBI is compelled to have know how of the below mentioned areas of concern:

1. What kinds of liquidity problems IBI has faced or facing along with their reasons?

2. What is the behaviour of IBI under the existing frame work of liquidity management and its influence on bank performance?

3. What are the Shariah compliant tools available to IBI to manage the liquidity problems and what additional gaps need to be filled in this respect?

The paper intended to study the risk the financial industry is exposed to, in perspective of types of liquidity problem, the reasons of liquidity problem and its impacts with the ultimate aim of finding a solution to the 
has a wide scope of application, not limited only to Pakistan but having the potential of global practicability as the salient characteristics of IBs are almost the same anywhere.

\section{Literature Review}

The gist of the business of banking industry is acceptance of funds from depositors, and, subsequent investment/lending of these funds in profitable and secure avenues. The revenue generated during the course of investment/borrowers goes on to be shared with the depositors. Higher levels of income create higher levels of depositor confidence in the banking institutions. However, there are varied risks underlying the activities of a bank. The broad classification of risk in financial institutions is as under:

1. financial risk,

2. business risk, and

3. operational risk.

Financial risk arises from the multiple business activities undertaken by banks. The business risk as well as operational risk has to do with the internal procedures of the bank. According to Ismal (2010), liquidity risk, along with credit risk and market risk, is categorized under the financial risk. Central Bank of Pakistan in its Risk management guidelines (2008) identified six categories of risk in Islamic banks which also include liquidity risk (State Bank of Pakistan, 2008):

- Credit risk

- Equity investment risk

- Market risk

- Liquidity risk

- Rate of return risk

- Operational risk

In a financial institution, all risks have inherent interrelationship and any single risk can trigger other risks, like market risk or credit risk may prompt liquidity risk and, in the same way, business risk as well as operational risk can also give rise to liquidity risk. In addition, liquidity risk in one bank has the potential likelihood of influencing the banking industry in aggregate, and, eventually affecting the entire economy. Thus the need for development of close cooperation among all the stake holders cannot be over emphasized. Also, it is necessary that the management of all the risks in financial industry should be arranged keeping an eye on the cause and effect and interrelated nature of all the risks (Ismal, 2010). Liquidity risk also arises from the disparity related to the maturities of the two sides of the balance sheet. This disparity either causes an excess of cash waiting to be invested or produces deficiency of cash that requires funding and is signals towards deeper fundamental weakness in the balance sheet that took roots over the course of years (Bank for International Settlement, 2009). Liquidity risk can be dangerously stimulated by assets liability imbalance or disparities in their maturities. A financial institution should have in place a system to estimate in advance the factors bringing into play business risks, financial risks along with operational risks which can lead to mismatch in assets and liabilities and therefore propel liquidity risk (Ismal, 2010). According to Hubbard (2002), the liquidity risk becomes an active force either when the deposit withdrawal exceeds the funds in hand with the bank, or, when the borrowers default in repayment of their financial commitments when they become due. The indispensable deliberation on liquidity risk management investigates in detail and revolves around the balancing of liquidity generation on the liability side with the requirement of the same on the asset side. Problems are faced in case of banks' inability to balance these two sides, shortfall in creation of sufficient internal liquidity reserves, and failure to generate funds externally (Ismal, 2010). The liquidity risk arises in Islamic banks as there are no well-structured Islamic money markets in most jurisdictions to generate liquidity when required, furthermore, most assets of Islamic banks are primarily debt-based and due to Shariah restriction on sale of debt, these become illiquid (Ahmed, 2009). According to Islamic Financial Services Board (2012), liquidity risk is the possible loss to Islamic Financial Institutions due to their incapability either to meet their commitments or to arrange funds for assets creation whenever need for the same arises, without having to bear intolerable expenditures or losses. Islamic financial institutions are engaged in conversion of maturities of funds from short term to long term by collecting short-term deposits and transforming them into medium and long term financing. This maturity transformation exposes Islamic banks to numerous risks, including liquidity risk as well (Islamic Financial Services Board, 2012). The global 
financial crisis 2008-2009 prominently illustrates and conspicuously highlights unsuccessful results in derivative markets, which affected the capability of financial institutions to furnish liquidity for further assets creation. Deficient liquidity caused a credit crunch, impeding the activities of real economy by diminishing banks' ability to fund a new project (Siddiqi, 2008). Such lower financing availability led to the collapse of the housing market, the aftermath of which was drastic reduction in housing prices. Interlinked relationships among risks in the financial sector spun up a chain reaction that brought the real economy to a halt. A problem initiated in the form of credit risks in no time gave birth to liquidity risks and market risks (Ahmed, 2009). The crisis has clearly demonstrated that the fading of liquidity plays a pivotal role in the shaking the structure of financial institution (Bank for International Settlement, 2009). The Islamic financial institutions remained protected from the impact of the global financial crises of 2008-2009, in most part due to idle liquidity and to some extent owing to its new emergence in the market, attracting inflows from the conventional banks, however due to extra liquidity; lower return was passed to IAH (Islamic Financial Services Board, 2012). Liquidity reflects the aptitude of a financial firm to incessantly maintain equilibrium between the financial inflow and outflow over time (Vento \& Ganga, 2009). Holding excess liquidity is another liquidity problem negatively affecting the profitability of an organization and it is very normal that some IBs have surplus funds while others are facing shortfall in liquidity. A balanced approach between the objective of profitability and safety leads to better Liquidity Management (Chapra and Habib, 2002). As far as Islamic banks are concerned, they are more susceptible to surplus liquidity problem because of their fundamental obligation to convert money into permissible assets which is a time consuming and sometimes a tedious taskand many times Islamic banks are left with surplus funds which seriously hinders the profitability objectives (Usmani, 2007). Islamic banks have a better liquidity status with surplus funds as compared to conventional banks whereas limited investment options impair bank profitability (Ika and Abdullah, 2011). According to Siddiqui (2009), Islamic banks are extremely liquid and find it very hard to manage excess liquidity because time is required to find an asset for Islamic banking. Though performance of some IBs is encouraging and can go much farther through development of the much needed financial instruments to absorb excess liquidity (Ahmed, 2001). Another constraint upon Islamic banks is that they cannot invest their reserve requirements with the regulator due to non-availability of Islamic instrument against the investment which is not the case for conventional banks (Abdullah et al., 2010). Islamic banks in Pakistan have no option but to place their surplus funds only with other Islamic banks under interbank agreements but this didn't prove to be an efficient liquidity management tool in view of excess liquidity position of most Islamic banks. To resolve this issue, Islamic sovereign bonds called IjarahSukuk were introduced by State Bank of Pakistan but due to long-term nature of IjarahSukuk and short-term nature of deposits, Islamic banks suffer from massive asset/liability mismatch. This is in addition to the interest rate risk they are exposed to when they invest long term at a fixed rate and have their liabilities frequently re-priced ("Islamic Banks in Liquidity spurt"

1). Islamic banks have shown impressive deposit growth but due to thin Islamic investment avenues,

Islamic institutions find it very hard to offer a good rate of return to depositors. Furthermore, considering the appetite of the Islamic market, the size of the Sukuk bonds is considered as peanut and it would not cater the excess liquidity in the market (Ijarah Sukuk: peanuts won't help, 2). Therefore conventional banks are at an edge over the Islamic banks because of availability of wide range of short term and long term securities for investment of surplus funds, but the opportunities for Islamic banking industry are few (Islamic Financial Services Board, 2008). Islamic banking industry is facing dearth of ample Shariah compliant money market instruments and financial assets of an Islamic bank cannot be converted into negotiable financial instruments (Mohd et al, 2009). Furthermore, nonavailability of Islamic T-bills is the single largest obstacle retarding growth of the Islamic financial industry (Siddiqui, 2009). The main responsibility lies with central bank. The Central Bank can provide Shariah compliant equitable return on deposit placed with it by recycling of Islamic Bank reserves and excess funds into Investments deposits with Islamic Banks (Kahf, 2009). The Central Bank needs to develop earning products amenable to Shariah to provide income on the deposits and reserves of Islamic banks, levelled with earning on conventional banks deposit and reserves (Kahf, 2012). Malaysia, Bahrain and the United Arab Emirates (UAE) have designed short-term international liquidity management schemes to meet their various investment requirements. However, Islamic financial markets are not well assimilated with the overall money markets in most jurisdictions (Abdullah et al., 2010). As compared to the GCC and SEA regions, which are at the core of Islamic finance, the rest of the world is in various phases of development of Islamic finance and has different issues. For instance, just like in Pakistan, Islamic banks in the UK are

obstructed as they are unable to place their reserve requirements with the regulator in a Shariahcompliant earning mode. New entrants such as China, Japan, South Korea, Australia, France and other countries are still struggling to set up Shariah-compliant liquidity arrangements. Majority of them are still 


\section{Research Methodology}

The model developed is a primary research using a questionnaire along with structured interviews of Shariah Advisors of Islamic banks. The respondents of the questionnaire were Islamic bankers working in Islamic banks or Islamic windows of conventional banks in Pakistan, placed at senior management and middle management levels, equipped with experience and knowledge of the topic. The focused cities were Lahore and Karachi which are seats of head offices of most of the banks. Moreover, the most experienced Shariah advisors from two Islamic banks were also taken on board for their structured interviews.

The population size was 40. Response from 32 respondents was received; six questionnaires were discarded. Therefore, sample size for this study was 26 along with interview of 2 Shariah advisors. The researcher strived to ensure that respondents had complete grasp of all the questions.

For demographic analysis of the respondents, software Statistical Package for Social Sciences was used (SPSS version 21) and descriptive statistical analysis technique was employed to scrutinize the data of questionnaire. For the purpose of the subject research, the study targeted senior and middle managers of Islamic banks as survey participants and following research question was designed accordingly:

\section{"Liquidity Management in Islamic Banks"}

The questionnaire constitutes two portions. The first portion comprises of questions A-G to check the respondents' demography along with their knowledge, qualification and experience about Islamic banking and the research topic. In the second portion, questions 1, 2.1-2.18, 4 and 6 aimed at contemplating the reasons affecting liquidity position of an Islamic bank. Questions 3.1-3.6 mulled over the behaviour of the Islamic banks during liquidity crunch. Questions 5.1-5.2, 8.1- 8.2, 9 and 12 pondered over the status of support and available Shariah compliant products at government and central bank level for IBI liquidity problem. Questions 7, 10, 11 and 13 bring forth the respondent's opinion in respect of applicability of the solutions proposed in the research. As for interviews of the Shariah advisors, these based on questions regarding current practices and issues of liquidity management of Islamic banks, central bank support regarding liquidity management and feasibility of the proposed solutions in the research for liquidity management. For the purpose of this study and development of the instrument and interviews with Shariah advisor, following hypotheses were developed:

H1: The securitization of existing long term assets portfolio of Islamic banking industry is positively related to the solution of liquidity problem.

$\mathrm{H} 2$ : Formation of common Musharikah pool among Islamic banks is positively related to the solution of liquidity problem.

\section{Conclusion from Interviews of Shariah Advisors}

The Shariah advisors opined that the liquidity problem is greatly impacting the performance of Islamic banks in two ways; some banks enjoy surplus in liquidity while others are marred by liquidity crunch and, in either of the situation, banks' profitability suffers negatively. There is no fixed and permanent solution to the problem and great deal of effort needs to be put in for the development of products for liquidity management in Islamic banks. The greatest problem is scarcity of Shariah compliant products and money market instruments which hinders even the Central bank from providing support to IBs on equal footing with that to conventional banks. Through securitization of existing long term assets portfolio, Islamic bank will be equipped with Islamic money market instruments by issuance of tradable Sukuk bonds representing real assets in the economy. The arrangement will facilitate Islamic banks during liquidity crunch and furnish liquidity via sale of these Sukuk bonds representing their own assets, and, simultaneously adjust surplus liquidity of another Islamic bank carrying the burden of surplus liquidity, through purchase of the Sukuk bonds. The process thus generated will redeem both angles of liquidity problem i.e. surplus or shortfall in liquidity, and thus the Islamic banking industry may be able to eradicate its obstructing complications. The most material element in this process in permanence in securitization of assets so that continuous availability of Sukuk bonds can be ensured in the market and whenever any bank needs liquidity, the bonds can be sold in the secondary market adjusting surplus liquidity of another bank. The issuance of Sukuk bonds through securitization can be linked with assets behind Ijarah and Diminishing Musharikah transactions as these transactions are very common and represent real assets till maturity of the contract. As for Common Mushariakah pool, it will be a common pool 
or interbank pool of the Islamic banking industry, regulated by Central bank, in which an Islamic Bank with surplus liquidity places surplus fund and through this pool another Islamic bank facing liquidity crunch gets funds to manage its shortfall. For the purpose of transparency, the role of Central Bank is extremely momentous and when this tool of interbank placement becomes operational in the market, the objective of prudent liquidity management can also be achieved. The creation of such a pool will be a milestone in development of Islamic banking industry which can create prospects for the Islamic banking industry to establish its own bench-mark rather than depend upon the conventional bench mark, which entails more research to be undertaken. Ulama already proposed such a product which is backed by assets. However, under the suggested system, there is no requirement of assets creation at pool or Central Bank level, rather representation of assets will be automatically made by an Islamic bank requiring liquidity from the pool.

\section{Findings of questionnaire}

It becomes crystal clear that majority of staff working at senior and middle management positions in Islamic banks possesses average level of knowledge of Islamic banking and Fiqh. The research illustrated that the liquidity problem in IBI is of double faceted in nature i.e. surplus liquidity and liquidity crunch and most of the Islamic banks faced both kinds of liquidity problem at different times. The fundamental factors yielding noticeable impact on the liquidity position of the bank are:

- Scarcity of Islamic money market products,

- Limited Islamic money market,

- Shariah constraints on many activities like bills discounting, sale of debt, and investment in treasury bills.

- Central bank policies

- Balance sheet structure of Islamic banks. On the assets side, repayment period and repayment amount is fixed whereas on the liability side, depositors can withdraw their amounts at any time.

- Network of the bank.

- Deposit blend along with historical profit rates on deposits.

- Assumptions in forecasting of future cash flows.

- Quality of assets portfolio.

It is safe to interpret that Islamic banks depend for the greater part on interbank support by obtaining liquidity from other banks through opening of their accounts along with support of parent company to manage liquidity crunch. The Islamic windows of conventional banks can fare much better to manage liquidity. The result of the research brings into limelight the mechanism prevalent among Islamic banks through which surplus liquidity is transferred to another Islamic bank under Mudarabah agreements. Majority of respondents opine that liquidity problem in Islamic banks can be addressed through securitization of existing long term portfolio of Islamic banks and the most feasible products are Ijarah and Diminishing Musharika. It can also be eradicated through formation of common Musharika pool among Islamic banks in which an Islamic Bank with surplus liquidity place their surplus funds and other Islamic banks facing liquidity crunch get funds to manage shortfall.

\section{Conclusions}

This conclusion can be derived from the research that the personnel discharging duties at senior and middle management positions in Islamic banks are at an average level regarding the necessary knowledge of Islamic banking and Figh. Thus role of Shariah advisor assumes all the more importance. It also becomes evident from the research that a host of different internal and external factors, as explained above, impact liquidity position of the Islamic banks. The liquidity problem in Islamic banks is of two types i.e. surplus liquidity and liquidity crunch and most of the Islamic banks faced both kinds of liquidity problem at different times. The results also shed light on the acute shortage of Islamic money market products to deal with the liquidity issues. However, to handle the problem, at the moment, Islamic banks generate interbank arrangement through opening of their accounts with each other under Mudaribah arrangements. As far as Central bank support to Islamic banks is concerned, though Central banks is positive in support to Islamic banks but its support level cannot be equated to that of conventional banks till the availability of Shariah compliant money market products. An encouraging initiative on the part of the conventional banks is the launching of 


\section{COMSATS Journal of Islamic Finance}

left in the lurch with a potently threatening asset-liability maturity mismatch. Results also highlight the comparatively better off status of Islamic windows of conventional banks as far as management of liquidity crunch is concerned, by obtaining funds from conventional treasury under Wakala and Musharikah agreements.

\section{Recommendations}

A glance at the results of the questionnaire and interviews of Shariah advisors is clear proof that securitization of existing long term portfolio of Islamic bank as well as formation of common Musharika pool among Islamic banks bear a positive relationship with the solution of liquidity problem.

The securitization of the assets portfolio of an Islamic bank will take the shape of Islamic marketable Sukuk bonds, and hence, marketable Islamic instruments of money market will be available. The marketability of these instruments will depend upon Sukuk issuing bank rating as well as quality of portfolio/assets representing Sukuk bonds. This instrument will enable the bank to generate liquidity from its own sources (assets) by selling Sukuk bonds in the Islamic bank industry (the banks with surplus liquidity) representing assets in the form of consumer cars/housing portfolio or corporate long term portfolio. At the same time, these Sukuk bonds will be able to absorb surplus liquidity of other Islamic banks. The proposed Musharikah pool can undertake dual functions simultaneously i.e. provide liquidity during liquidity crunch and, at the same time, absorb surplus liquidity in the market. The banks with surplus liquidity will have access to an immediate source of investment, and, decision making for investment will undoubtedly gain better quality because urgency in managing surplus liquidity will be reduced. On the other hand, the bank in a liquidity crunch will have an immediate source of funds through Musharika pool. As a result, it will be able to control its cost of deposit which normally banks need to do, in order to get out of liquidity crunch. Over and above all other factors, Musharika pool may prove a pivotal force in the establishment of liquidity equilibrium in the Islamic banking Industry.

\section{References}

Abdullah, A., \& Khan, A. Q. (2012). Liquidity Risk Management : A Comparative Study between Domestic and Foreign Banks in Pakistan. Journal of Managerial Sciences, 6(1), 61.

Abdullah, D. V. Leadlamic Financial Services. In Second Islamic Financial Stability Forum Jeddah, Kingdom of Saudi Arabia (p. 19). Jeddah. Retrieved from www.ifsb.org/docs.

Ahmed, H. (2009). Financial Crisis : Risks and Lessons for Islamic Finance. ISRA International Journal of Islamic Finance, 1(1), $7-32$.

Ahmed, H. and K. T. (2007). Risk Management in Islamic Banking (chapter 10) in Handbook of Islamic Banking. (M. K. Hassan \& M. K. Lewis, Eds.). United Kingdom: Edward Elgar Publishing Inc.

Ahmed, N., \& Usman, M. (2011). Risk Management Practices and Islamic Banks : An Empirical Investigation from Pakistan. Interdisciplinary Journal of Research in Business, 1(6), 50-57.

Ahmed, O. B. (2001). Islamic Financial Instruments to Manage Short-Term Excess Liquidity. IRTI/IDB Research Paper No. 41 , $1-106$.

Akhtar, M. F., Ali, K., \& Sadaqat, S. (2011). Liquidity Risk Management : A comparative study between Conventional and Islamic Banks of Pakistan. Interdisciplinary Journal of Research in Business, 1(1), 35-44.

Bank for International Settlement. (2008). Liquidity Risk: Management and Supervisory Challenges. Bank for International Settlement Paper, Basel Committee on Banking Supervision, Basel,.

Bank for International Settlements. (2006). The management of liquidity risk in financial groups. Bank for International Settlement Paper, The Joint Forum Basel Committee on Banking Supervision, Basel,

Bank for Internatiotional Settlements. (2008). Principles for Sound Liquidity Risk Management and Supervision (pp. 1-42).

Batunanggar, S. (2002). Indonesia's banking crises resolution: Lessons and the way forward. In Banking Crisis Resolution Conference, CCBS, Bank of England (p. 47). London.

Borio, C. (2009). Ten propositions about liquidity crises. Bank for International Settlement Working Paper no 293, Monetary and Economic Department.

Brunnermeier, M. K., \& Pedersen, L. H. (2007). Market liquidity and funding liquidity. Review of Financial Studies, 22(6), 2201-2238. Retrieved from http://eprints.lse.ac.uk/24478/

Business Recorder (2013), "Islamic banks in liquidity spurt", 17 June, p. 1.

Business Recorder (2014), “Ijarah Sukuk: peanuts won’t help”, 20 June, p. 2.

Chapra, M. U., \& Habib, A. (2002). Corporate Governance in Islamic Financial Institutions. Occasional Paper No. 6, Jeddah, IRTI/IDB.

Clementi, D. (2001). Financial markets: implications for financial stability. Balance Sheet,9(3), 7-12.

Ernst \& Young. (2013). World Islamic Banking Competitiveness Report. Ernst \& Young (pp. 1-21). Estrada, D., \& Osorio, D. R. (2006). A Market Risk Approach to Liquidity Risk and Financial Contagion. Ensayos sobre Política Económica, 21(6), 275-280. 
Fiedler, R. E. (2000). Liquidity Risk (Chapter15) in The Professional's Handbook of Financial Risk Management. In M. Lore \& L. Borodovsky (Eds.), (pp. 441-471). Reed Educational and Professional Publishing Ltd.

Gray, S. T. (2006). Central bank management of surplus liquidity. Centre for Central Banking Studies, Bank of England, London. London. Retrieved from http://www.jstor.org/discover/10.2307/2330107?uid=3738832\&uid=2129\&uid=2\&uid=70\&u id $=4 \&$ sid $=21102771322811$

Greuning Hennie and Iqbal, Z. (2009). Balance sheet analysis : Islamic vs . conventional, New Horizon Islamic Banking Global perspective on Islamic banking \& Insurance. Institute of Islamic Banking and Insurance, 1-3.

Hanif, M. (2011). "Differences and Similarities in Islamic and Conventional Banking." International Journal of Business and Social Science, 2(2), 166-175.

Hanif, Muhammad and Iqbal, A. M. (2012). Inside-Out : Perception of Key Finance Professionals about Theory and Practice of Islamic Banking National University of Computer \& Emerging Sciences. International Journal of Humanities and Social Science, 2(4), 198-208.

Hasan, M., \& Dridi, J. (2010). IMF Working Paper, The effects of the Global Crises on Islamic and Conventional Banks, 1-47. Retrieved from http://www.imf.org/external/pubs/ft/wp/2010/wp10201.pdf

Iqbal, Z., \& Mirakhor, A. (2007). An Introduction to Islamic Finance Theory and Practice (pp. 83-31). John Wiley \& Son Pte Ltd. Retrieved from

http://www.scribd.com/doc/64913115/An-Introduction-to-Islamic-Finance-Theory-and-Practice

Islamic Financial Services Board. (2006). Guiding Principles on Corporate Governance for Institutions offering only Islamic Financial Services (excluding Islamic Insurance (Takaful) Institutions and Islamic mutual funds) (pp. 1-33).

Islamic Financial Services Board. (2008). Technical Note on issues in Strengthening Liquidity Management of Institutions offering Islamic Financial Services: The Development of Islamic Money Markets (pp. 1-104).

Islamic Financial Services Board. (2009b). Guiding Principles on Shariah Governance Systems for Institutions offering Islamic Financial Services (pp. 1-39).

Islamic Financial Services Board. (2012a). Guiding Principles on Liquidity Risk Management for Institutions offering Islamic Financial Services [excluding Islamic Insurance (Takaful) Institutions and Islamic Collective Investment Schemes].

Islamic Financial Services Board. (2012). Guiding Principles on Stress Testing for Institutions offering Islamic Financial Services [excluding Islamic Insurance (Takaful) Institutions and Islamic Collective Investment Schemes] (pp. 1-63).

Ismail, A. G. (2010). Islamic banks and wealth creation. ISRA Research Paper No. 9/2010, Kuala Lumpur, 16. Ismal, R. (2010b). The management of Liquidity Risk in Islamic Banks: The case study of Indonesia in Islamic banks. Durham University. Retrieved from http://etheses.dur.ac.uk/550/

Ismal, R. (2010c). Assessment of liquidity management in Islamic banking industry. International Journal of Islamic and Middle Eastern Finance and Management, 3(2), 147-167. Retrieved from http://www.emeraldinsight.com/journals.htm?articleid=1864446

Ismal, R. (2010d). How Do Islamic Banks Manage Liquidity Risk? An Empirical Survey on the Indonesian Islamic Banking Industry. Kyoto Bulletin of Islamic Area Studies, 3(2), 54-81.

Ismal, R. (2010). Volatility of the returns and expected losses of Islamic bank financing. International Journal of Islamic and Middle Eastern Finance and Management, 3(3), 267-

279. Retrieved from http://www.emeraldinsight.com/journals.htm?articleid=1881402\&show=pdf Jagne, M. M. (2000). Liquidity Management Fund for Islamic Banks, 11.

Kahf, M. (2009). Treatment of Excess Liquidity in The Arab Gambian Islamic Bank. Retrieved from http://www.iefpedia.com/english/?p=3954

Kamaluddin, N., Manan, S. K. A., \& Sufian, F. (n.d.). Shari ' ah Principles of Sukuk Structure in Malaysia Islamic Capital Market, (2009), 1-10.

Lou, X., \& Sadka, R. (2010). Liquidity Level or Liquidity Risk ? Evidence from the Financial Crisis. papersssrncom. SSRN. doi: $10.2139 /$ ssrn. 1622885

Metwally, M. M. (1997). Differences between the Financial Characteristics of Interest-Free Banks and Conventional Banks. European Business Review., 97(2), 92-98. Retrieved from http://papers.ssrn.com/sol3/papers.cfm?abstract_id=2158086 Mohd Ariffin, N., Archer, S., et al. (2009). Risks in Islamic banks evidence from empirical research. Journal of Banking Regulation, 10(2), 153-163.

Parashar, S., and Venkatesh J. (2010). How did Islamic banks do during global financial crisis?, Banks and Bank system5(4), 54-62. Rosman, R. (2009). Risk Management Practices and Risk Management Processes of Islamic Banks: A Proposed Framework. International Review of Business Research Papers, 5(1), 242-254.

Saxegaard, M. (2006). Excess Liquidity and Effectiveness of Monetary Policy: Evidence from Sub- Saharan Africa. IMF Working Paper No. 06/115

Siddiqi, M. N. (2008). Current Financial Crisis and Islamic Economics. Lecture paper in the long distance IDB courses in Islamic Banking and Finance. Retrieved from http://www.siddiqi.com/mns/CurrentFinancialCrisisAndIslamicEconomics.htm Siddiqui, I. (2009), “Islamic Banks face Excess Liquidity”, The News, 8 February. Retrieved from http://ibfn.wordpress.com/2009/02/08/islamic-banks-face-excess-liquidity-pakistan

State Bank of Pakistan. (2008). Risk Management Guidelines for Islamic Banking Institutions (pp.1-19). Retrieved from www.sbp.org.pk/ibd/2008/Annex-c1.pdf

State Bank of Pakistan. (2011c). GOP Ijarah Sukuk. Govenrment of Pakistan Security, Investor Guide (pp. 1-7).

State Bank of Pakistan. (2012b). Instructions for Profit $\mathcal{E}$ Loss Distribution and Pool Management for Islamic Banking Institutions (IBIs) (pp. 1-9). 


\section{COMSATS Journal of Islamic Finance}

State Bank of Pakistan. (2013b). IHESMEFD Circular Letter No. 05 of 2013 regarding Eligibility of Government of Pakistan (GoP) Ijara Sukuk in Musharaka Pool.

Usmani, M. I. A. (n.d.). Examining the prudence of Islamic banks: A risk management perspective, 1-4. Retrieved from http://meezanbank.com/docs/

Usmani, M. I. A. (2002). Meezan Bank's Guide to Islamic Banking. (Z. Zubairi, Ed.) (p. 217). Karachi: Darul-Ishat Urdu Bazar Karachi-1, Pakistan.

Usmani, T. (1996). What Shariah Experts Say Futures, Options and Swaps. International Journal of Islamic Financial Services Vol. 1 No.1, 1(1), 1-3.

Vento, G. A., \& Ganga, P. La. (2009). Bank Liquidity Risk Management and Supervision: Which Lessons from Recent Market Turmoil? Journal of Money, Investment and Banking, (10), 78-125. Retrieved from www.eurojournals.com/JBIM.htm 